\title{
A VIDA SACRA E O PURO-NÃO: ENTRE HISTÓRIA E SUBJETIVIDADE
}

\author{
THE SACRED LIFE AND PURE-NO: BETWEEN HISTORY AND SUBJECTIVITY
}

Ricardo Prestes Pazello*

\begin{abstract}
Resumo
Tomando como ponto de partida a estética do puro-não, decorrente da interpretação do poema de Oliverio Girondo, o presente ensaio busca compreender as formas de negação da vida como estratégia política e como relação ética. Dialogando com a genealogia do estado de exceção, de Marx a Agamben, constrói-se uma reflexão filosófica acerca da vida sacra que, no contexto brasileiro, pode ser visualizada nos casos de criminalização de movimentos sociais. O caso aqui estudado é o do Movimento dos Trabalhadores Rurais Sem-Terra e a ação judicial que propôs sua dissolução. A possibilidade da vida surge do próprio puro-não, na medida em que este se diferencia do nada, e permite a ascensão de subjetividades coletivas contra-hegemônicas.
\end{abstract}

Palavras-chave: Vida sacra; puro-não; movimentos sociais; criminalização.

\begin{abstract}
Taking as starting point the aesthetics of pure-no, regarding the interpretation of the põem of Oliverio Girondo, this essay seeks to understand the ways of negation of life both as a strategy and as ethical relationship. Dialoguing with the genealogy of the state of exception, from Marx to Agamben, it is possible to do a philosophical reflection on the sacred life that, in the Brazilian context, can be seen in cases of criminalization of social movements. The case studied here is the Landless Rural Workers' Movement and the lawsuit which has proposed its dissolution. The possibility of life arises from the pure-no itself, because pure-no differs from nothingness, and allows the rise of counter-hegemonic collective subjectivities.
\end{abstract}

Keymords: Sacred life; purê-no; social movements; criminalization.

\section{Profanando o puro-não: uma introdução}

Este é um trabalho que envolve subjetividade e senso histórico. Poderiam parecer os dois como que antitéticos ou até, para os mais afoitos, antinômicos. Quando muito, um estaria sujeito ao outro. Mas não. Não é essa base a que informa este escrito. Em verdade, a

\footnotetext{
* Professor de Antropologia Jurídica no Curso de Direito da Universidade Federal do Paraná (UFPR). Secretário geral e pesquisador do Instituto de Pesquisa, Direitos e Movimentos Sociais (IPDMS). Secretário administrativo do Centro de Formação Milton Santos - Lorenzo Milani (Santos-Milani). Pesquisador do Núcleo de Estudos Filosóficos (NEFIL/UFPR), do grupo de pesquisa Direito, Sociedade e Cultura (FDV/ES) e do Instituto de Filosofia da Libertação (IFiL), nas seguintes linhas temáticas: "Direito e Marxismo na América Latina", "Teorias Críticas, América Latina e Epistemologias do Sul” e "Antropologia Jurídica, Movimentos Populares e Comunidades Tradicionais". Coordenador dos projeto de extensão popular universitária Direito e Cidadania (UFPR). Doutorando em Direito das Relações Sociais pelo Programa de Pós-Graduação em Direito da Universidade Federal do Paraná (PPGD/UFPR). Mestre em Filosofia e Teoria do Direito pelo Curso de PósGraduação em Direito da Universidade Federal de Santa Catarina (CPGD/UFSC). Bacharel em Direito pela Universidade Federal do Paraná (UFPR). Colunista do blog assessoriajuridicapopular.blogspot.com. E-mail: ricardo2p@ufpr.br
} 


\section{RICARDO PRESTES PAZELLO}

subjetividade não se desistoriciza ao se pretender digna de lugar no mundo. Não partilhamos, aqui e portanto, de nenhuma ideologia individualista, nenhuma sensaboria que a hipermodernidade encorajou como seu não-jargão. Também assim, uma mirada histórica puramente determinada por sua estrutura (que repetidamente hoje sói ser chamada de "problemas estruturais") não tem vez entre nós. Subjetividade e história, dois traços indeléveis de nossa humanidade (muitas vezes, sem dúvida, quase inumana), já foram sobejamente entrelaçadas e não seremos nós os que cometeremos a desfaçatez de desenovelálas. Nossa responsabilidade, crítica e denunciante, não se afirmará novidadescamente (desatando o nó subjetividade-história) nem tampouco encobrindo seu pressuposto enfaticamente esquecido nos últimos tempos (deixando escamoteado o referido nó).

Historicamente, os tempos atuais têm sido noturnos. Mas disto nos ocuparemos adiante. À ribalta, agora, coloquemos a subjetividade. Informada por sua historicidade, ela medra com surpresas e assaltos. E surpresa e assalto é o pavimento que a consubstancia em texto, neste texto. Abrir ao léu um livro - que como todo livro é livro de areia porque infinito, nunca passível de completude - e chegar à medula é assustador. Assusta porque diz. E quem disse foi Oliverio Girondo, em seu acachapante "El puro no" (GIRONDO, 1999, p. 231):

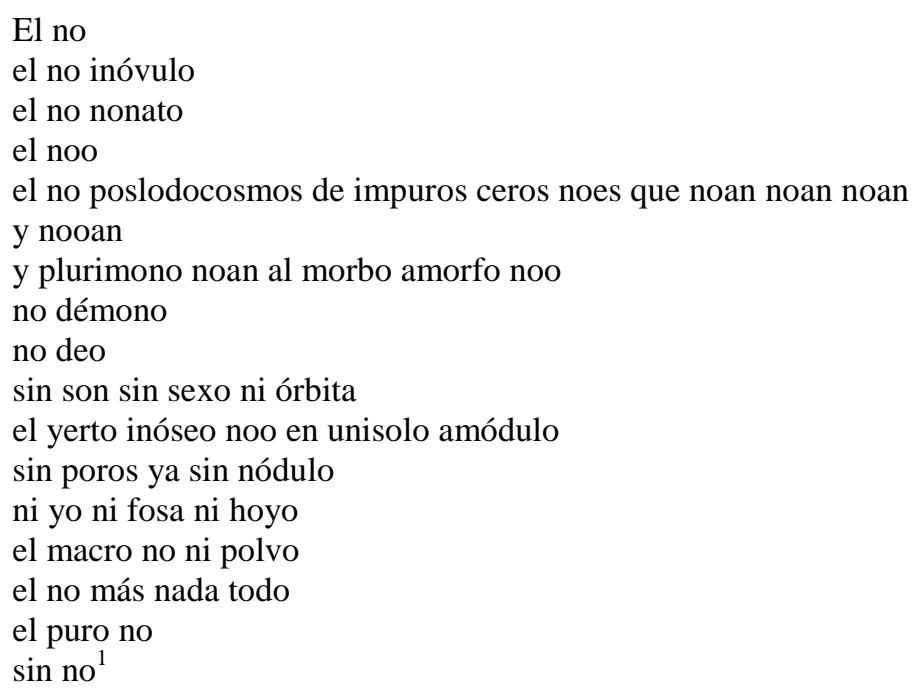

Ao acaso nos chegou este poema mas não por acaso aqui se encontra lembrado. A partir de nós, ganha uma possibilidade, uma visibilidade: "artificiosa, la visibilidad de un poema no es dada sino construida. No está en el autor sino en sus lectores" (ANTELO, 1999, p. LXXXVII). Portanto, não há interpretação fidedigna, sequer há alguma interpretação e sim, 
como quer Antelo, um "espectro". Mais ainda, "El puro no" é mais inspiração, porque indecidibilidade e filosofia política.

O ponto de partida é o não, logo, a negatividade. É uma negação que passa pelo nada, pelo eu, pelo sacro (ainda que nem deus ou demônio). De onde se parte, então, temos um programa de análise. Veremos aonde chegaremos - e já adiantamos que é no puro-não mas o que importa, por ora, é de onde saímos.

Este local - certamente, atópico - nos deixa no vazio. Talvez o vanguardista poético que fora o argentino Girondo estivesse pouco preocupado com o próprio uso de seu innão. Quiçá, nem mesmo uso tivesse. A mórbida negação nos serve, todavia, como instrumento porque, como veremos, ela se nega a si mesma. E ao fazê-lo, ao menos esta é nossa perspectiva (uma possível visi-bilidade), nos cai à mão como um brinquedo. E como crianças enfeitiçadas pelo novo passatempo, vemo-nos profanando as suas prováveis intencionalidades. Seja uma moeda ou uma cruz, um poema ou um pedaço de pão, a criança cria (como atesta a mão-dupla de sua etimologia) e inventa e realoca e remobiliza a "coisa" como se nunca tivesse sido sagrada: “en arte, en poesía, nada más importante que el recuerdo, ni más indispensable que saber olvidar" (GIRONDO apud ANTELO, 1999, p. XLVI). Estão, assim, as crianças a meio passo de serem poetas, porque, ainda que não recordem, sabem muito bem esquecer.

Este puro-não, que não é teoria pura do não porque não pode nem deve sê-la, este puro-não começa a ser profanado por nós. Entre os juristas romanos o profanar era presente: "se consagrar (sacrare) era o termo que designava a saída das coisas da esfera do direito humano, profanar, por sua vez, significava restituí-las ao livre uso dos homens" (AGAMBEN, 2007d, p. 65). Aqui, salientamos que já partimos por profanar a própria profanação, uma transprofanação que não aceita o mitologema jusromanocêntrico do direito. De qualquer forma, fica para nós a passagem do ritual ao jogo, tão caro este às crianças e que desarma (porque a arma é de brinquedo) o dispositivo religioso que não religa mas sim relê - assim, separando - a terra pelos dogmas do céu ou, nas trilhas de Benjamin, a humanidade pelo capitalismo. Desse modo, espetáculo e consumo, “duas faces de uma única impossibilidade de usar" (AGAMBEN, 2007d, p. 71) são o hodierno improfanável. Para desativar estes dispositivos estão aí as novas crianças, a geração que vem, para cumprir tão importante tarefa política.

R. Fac. Dir. UFG, v. 38, n. 2, p. 121 - 148, jul. /dez. 2014

ISSN 0101-7187 
No âmbito da profanação, portanto, o poema, que tão bem se ajusta às mãos dos críticos literários, vira brinquedo. Em um sacro, ainda que interessante, estudo sobre Girondo, uma crítica literária pôs sobre o altar, distante dos crentes, a sua poesia, "El puro no" inclusive. Dela extraímos o principal: Girondo trabalha a palavra como timbre e estrutura, ou seja, consoantes e vogais que se chocam para construírem o texto e darem o tom de sua musicalidade; também, as palavras se aliteram e se reduplicam; e mais, o constituinte dos poemas é enfatizado caudalosamente. Timbre/estrutura, aliteração/reduplicação e ênfase (NOBILE, 1972) marcam os poemas de "En la masmédula" e, especialmente, "El puro no", que o integra. Mas é só o que nos diz o sagrado. O profano é o que aparecerá de agora em diante: estrutura como história, ênfase como subjetividade e repetição como a mediação do texto do puro-não.

Nosso caminho "metodológico", portanto, é o de realizar um ensaio de interpretação, inspirado no puro-não de Girondo, acerca da estratégia política do contemporâneo de negar a vida. Na América Latina, a vida sacra tem de perder seus ares abstratos e é por isso que, mesmo seguindo a genealogia de Agamben (que iniciamos com Marx), podemos chegar, escatologicamente como se verá, à criminalização de movimentos sociais, não para aplicar sobre eles uma teoria eurocentrada, mas para profanar esta mesma teoria inspirados pela poesia. No fundo, um pretexto para evidenciar - e tornar mais palatável para a intelectualidade abstrata, porque traduzido (mesmo que não pretensiosamente) - um caso limite envolvendo o Movimento dos Trabalhadores Rurais Sem-Terra.

\section{As profecias negativas}

Ao sugerir a profanação como modus operandi do novo, o inominável que só poderá ser levado a cabo pela "geração que vem", Giorgio Agamben enuncia a existência de "três grandes profetas da modernidade", quais sejam, Nietzsche, Marx e Freud. Aterradoramente, informa-nos o filósofo italiano - e nesta tarefa segue a senda de Benjamin que nem por isso os três deixam de conspirar com o capitalismo, religião do desespero e da culpa da modernidade, que visa à destruição e não à transformação do mundo.

Para melhor entendê-lo, retomemos Nietzsche que, em sua "Genealogia da moral", toma como exemplo do que sejam os ideais ascéticos que eivam a modernidade a R. Fac. Dir. UFG, v. 38, n. 2, p. 121 - 148, jul. /dez. 2014 
postura adotada por Wagner ao elaborar seu "Parsifal". Sempre fora Wagner um cultor da castidade, mas antes não se opunha ele à sensualidade. Porém, o artista torna-se o seu contrário e os suínos são levados a adorar a castidade ascética. Teria sido uma piada o "Parsifal" inocente da aldeia, puro e cheio de castidade? Era o desejo de Nietzsche, mas não parece ter sido a realidade, aparentando-se mais com o abandono da sensualidade sadia feuerbachiana. Para Nietzsche, o caso de Wagner é típico e penoso. Por isso, o melhor é separar artista e obra, fazendo daquele precondição, esterco e adubo para esta. Com "Parsifal", Wagner caiu em uma perversidade intelectual. O artista inteiro e consumado deve sempre se divorciar do real/efetivo. Se rompe esta regra, surge a típica veleidade do artista, a qual, inclusive, fez o velho Wagner sucumbir. Então, os ideais ascéticos para o artista são absolutamente nada ou a tal ponto tudo que só podem ser nada.

Tais "ideais ascéticos" se aproximam do "puro não" de Girondo, não como prescrição, como fica evidente, e sim como espécie de tardia denúncia que se torna visível ao leitor mais tardio ainda de seus versos. Descrição, portanto, que se aproxima à de Nietzsche, sem perder, porém, sua historicidade.

Propõe-se Nietzsche a expor o que o ideal ascético significa e não o que ele realizou. Para isso, interroga-se sobre o sentido da imensidão de seus efeitos, de seu imenso poder. Mas questiona também onde está o ideal contrário. Exemplifica com a ciência: forma mais recente e mais nobre do ideal ascético; onde ela não é isto, apresenta-se como inquietude da ausência de ideal. Os últimos idealistas em ciência, os descrentes, os que acreditam ser os adversários do ideal ascético não passam de sua mais alta manifestação, estando longe de serem espíritos livres. Isto porque a fé (crença) não demonstra, não estabelece verdade, só probabilidade de ilusão. Assim, o que força à incondicional vontade de verdade é a fé no próprio ideal ascético, um valor metafísico, um valor em si de verdade. Com a negação do ideal ascético surge um novo problema: a crítica ao valor de verdade. É nessa esteira que Nietzsche aprofunda sua crítica à ciência, dizendo que ela e o ideal ascético, por serem aliados, devem ser combatidos em conjunto. Quer dizer: a vitória de Kant sobre os conceitos teológicos em nada prejudica e ofusca o ideal ascético. Pois bem, em sua crítica, Nietzsche alveja os cientistas acusando a historiografia moderna de só descrever - ascetismo e niilismo maiores. Aos contemplativos dirige, por sua vez, a acusação de que são ainda piores, vez que desonestos, pois o ideal ascético honesto ainda pode ser respeitado. 
O ideal ascético só tem um inimigo: os comediantes desse ideal. Na esfera espiritual, trata-se do ateísmo, o qual, portanto, não é ateu quanto à vontade de verdade. O que venceu o cristianismo como dogma foi sua própria moral. Resta saber agora se o cristianismo como moral também perecerá, fruto do problema posto para a consciência da vontade de verdade.

E como não remeter a Marx, quando Nietzsche dizia aprofundando esta idéia:

\begin{abstract}
acredita-se realmente que a derrota da astronomia teológica, por exemplo, representa uma derrota desse ideal [o ideal ascético]? Teria o homem menos necessidade de recorrer ao além para solucionar seu enigma de existir, agora que esse existir aparece como ainda mais gratuito, ínfimo e dispensável na ordem visível das coisas? Precisamente a autodiminuição do homem, sua vontade de diminuir-se, não se acha em avanço irresistível desde Copérnico? (NIETZSCHE, 2006, p. 142).
\end{abstract}

O paralelo encontrado com Marx surge no seguinte trecho de "A questão judaica":

\begin{abstract}
a emancipação política do judeu, do cristão e do homem religioso em geral é a emancipação do Estado do judaísmo, do cristianismo e, em geral, da religião. De modo peculiar a sua essência, como Estado, o Estado se emancipa da religião ao emancipar-se da religião de Estado, isto é, quando o Estado como tal não professa nenhuma religião, quando o Estado se reconhece muito bem como tal. A emancipação política da religião não é a emancipação da religião de modo radical e isento de contradições, porque a emancipação política não é o modo radical e isento de contradições da emancipação humana (MARX, 2005a, p. 20).
\end{abstract}

Nietzsche arremata indicando que o ideal ascético significou o sentido do sofrimento para o homem. Seu problema não é sofrer - ele até o deseja! - mas sofrer sem sentido. O sofrimento, assim, pôde ser interpretado e a lacuna, preenchida com a noção de culpa. Eis a vontade do nada, que ainda assim continua sendo vontade. Sem o ideal ascético o homem não teve sentido algum, por isto "qualquer sentido é melhor que nenhum”, é preferível “querer o nada a nada querer” (NIETZSCHE, 2006, p. 149).

Sugestivo é o apontamento da necessidade de um sentido que se conduz pelo ideal ascético. Assim, resgatando o poema por nós profanado, é melhor querer o puro-não que o puro-não dominar o querer. Isto para os ascetas nocauteados por Nietzsche.

Já Marx não se recobre pela hipocrisia e faz desfalecer a bem-comportada crítica de seu tempo, reivindicativa do espaço ao sol que deve ser dado a todo homem. Espaço ao sol 
que, de tão pedido, tornou-se a única recompensa destes pedintes - o banho de sol do presidiário. A emancipação política até se conseguiu, mas a custa de se manietar mais e mais as possibilidades da emancipação humana. Só a profanação pela geração que vem pode desamarrar essas mãos invisibilizadas, as quais se tornaram improfanáveis por serem não visíveis. O espectro do poema já se visibilizou. Cabe agora dar visibilidade a suas conseqüências.

O mosaico de cores que se pode fazer ver desoculta uma importante genealogia que também tem em Nietzsche um de seus vaticinadores. Mais profeta que artista, foi ele um dos primeiros a dar corpo ao texto que, de uma forma ou outra, já se escrevia na boca de tantos e tantos visionários, desde Tomás Morus até o século XIX: "do mais alto ponto de vista biológico, os estados de direito não podem senão ser estados de exceção, enquanto restrições parciais da vontade de vida que visa o poder" (NIETZSCHE, 2006, p. 65).

Como profeta e cúmplice da modernidade, é-nos difícil delimitar a fronteira em que Nietzsche trabalha, uma vez que sua denúncia do ideal ascético daqueles que denunciam este ideal pode parecer tão ascética quanto (ao menos este é o indicativo agambeniano), mas sua profecia (não tanto revelação de futuro mas mais desvelamento do passado) é essencial para compreender o ascetismo do estado de direito. Todo estado de direito é estado de exceção, assim como a emancipação do estado da religião não é emancipação da religião do estado.

Levar às últimas conseqüências o paralelo entre Nietzsche e Marx, provavelmente, também nos conduziria ao puro-não, que não é niilismo, mas sua superação. Niilismo, para nós, é o que nos sugere Girondo:

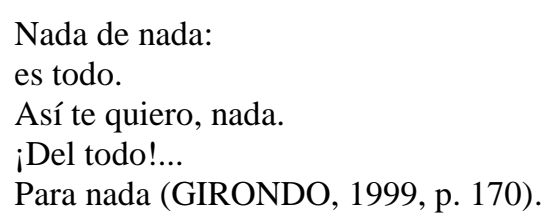

No entanto, vamos procurar abrir uma clareira em ponto diferente desta mata que insiste em permanecer fechada e densa. E a diferença entre "niilismo" e "o puro não" logo aparecerá. 


\section{RICARDO PRESTES PAZELLO}

Se é certo que Nietzsche e Marx andam por caminhos diferentes, não é menos certo que se tangenciam em sua caminhada. Não se trata, é claro, de supor que se leram reciprocamente ou que, numa mirada excessivamente realista, se afinaram teoricamente. Mas, isto sim, de perceber que se preocupavam, de um modo ou de outro, com a mesma coisa. Não sem fundamento seria encontrar uma aproximação entre eles, ainda que às avessas, quando o primeiro persiste nas críticas a Dühring, "o maior fanfarrão da moral que existe atualmente" (NIETZSCHE, 2006, p. 113), um autêntico homem de ressentimento que se quer vingar dos felizes, aqueles comprometidos com o futuro do homem. Marx seria um de seus alvos prediletos. Sendo este preocupado com o futuro do homem, não poderia passar desapercebido pelo homem de ressentimento Dühring, o qual lhe destina os três volumes de sua "teoria socialista minuciosamente elaborada, como também um plano prático completo para a reorganização da sociedade" (ENGELS, s. d., p. 7). Nada menos do que tudo. O puro nada. Quem nos narra esta história é Engels, ${ }^{2}$ cuja incumbência seria a de responder as críticas do “apóstolo da vingança berlinense” (NIETZSCHE, 2006, p. 113).

Por certo, não podemos também ser levianos e pôr em relevo desmedidamente o que tangenciou ambos os autores. Talvez um estivesse perfeitamente enquadrado na crítica do outro (o cientificismo de um, a burguesia do outro), mas a nossa atividade profanatória não se escusaria em realçar tão sugestivas interações entre profetas.

Marx também é o pivô de outra interação com o terceiro dos profetas da modernidade - Freud. Em reveladora abordagem acerca da obra de arte frente à mercadoria, Agamben permite um diálogo tartamudeado entre os dois loquazes vates modernos. Parte sua reflexão do problema do fetichismo. Em Freud, o fetichismo seria a substituição do pênis ausente da mãe, para o menino. Reconduzindo "o fenômeno do fetichismo aos processos inconscientes que constituíam a sua origem" (AGAMBEN, 2007b, p. 61), Freud vê uma recusa (ou, na tradução literal de "Verleugnung", negação, renegação) de o menino tomar consciência da ausência aludida como sua causa principal. Dessa forma, porém, a negação se transforma em presença do nada e, ao mesmo tempo, sinal de sua ausência. O objeto-fetiche adquire, portanto, estatuto ambíguo, vez que como presença se mostra concreto e tangível, mas como ausência, por dedução, imaterial e intangível.

A presença do nada estratifica-se em um niilismo que quer o nada: "do todo! Para nada”. Sob a regência do nada, só o niilismo pode se fazer de destino. O não, ao contrário, a R. Fac. Dir. UFG, v. 38, n. 2, p. 121 - 148, jul. /dez. 2014 
consciência da ausência do pênis materno, pode levar a outras paragens. Antes, porém, vejamos o que tem a nos dizer Marx.

Em Marx, por sua vez, seria o caráter místico do produto do trabalho após assumir a forma de mercadoria que caracterizaria o fetichismo. Lastreado pela dupla necessidade de caracterizar a sociedade capitalista de tal forma a encará-la em um mesmo processo, a reificação do homem e a fetichização da mercadoria, Marx possibilita-nos enxergar o que o capitalismo engendra: tal qual um grande teatro, os homens se tornam cenário, enquanto que as coisas, personagens.

De uma ou outra forma, é a "coisa" que ganha um sopro de vida - ainda que de vida não se trate - tanto em Marx quanto em Freud. A palavra "fetichismo" origina-se no português; "feitiço" é sua gênese etimológica. A "coisa", sacralizada, ganha um enfeite especial, ou seja, é feita animação, enfeitiça-se e domina os homens, mesmo que não cabalmente. Aqui, nem subjetividade nem história se submetem integralmente a esta dinâmica. Contudo, uma sua parcela se mantém subjugada, na medida da própria submissão relativa - dos homens concretos. Em outras palavras e seguindo Agamben, "à sobreposição do valor de troca sobre o valor de uso corresponde, no fetichismo, a sobreposição de um valor simbólico particular sobre o uso normal do objeto" (AGAMBEN, 2007b, p. 68). Como a base das análises de Marx é a bifurcação dos valores do objeto em valor de uso e valor de troca, vê-se que o fetichismo tem assento no segundo, apesar de não se dever confundir os dois. Fetichismo e valor de troca estão de braços dados mas não se confundem. ${ }^{3}$

Vemos, portanto, que o fetichismo, desde as duas abordagens, envolve objetos que são enfeitiçados, tornando-se, assim, sacros. Cabe a nós, como integrantes da "esfera do humano", reapropriarmo-nos de tais objetos dando-lhes um "livre uso", vale dizer, profanando-os. Então, mercadoria e objeto-fetiche não serão mais concretização de mais-valia ou somatização da psique patológica senão dispositivos desativados prontos para a brincadeira das crianças que vêm. Mas atenção: não sejamos ingênuos de considerar que isto é possível sem dessacralizar a religião moderna, o capitalismo, "gigantesco dispositivo de captura de meios puros, ou seja, dos comportamentos profanotórios" (AGAMBEN, 2007d, p. 76).

A este respeito, inclusive, Freud se pronunciou em seu " $O$ mal-estar na civilização". Trata-se de passagem em que aponta para a existência de um superego cultural R. Fac. Dir. UFG, v. 38, n. 2, p. 121 - 148, jul. /dez. 2014 


\section{RICARDO PRESTES PAZELLO}

análogo ao do indivíduo. Interessa-nos assinalar, aqui, que Freud, ao desenvolver sua idéia de civilização, encontra dois objetivos inscritos nela, vale dizer, ver os homens protegidos de sua própria natureza e realizar o ajuste dos relacionamentos destes mesmos homens entre si. Estes anelos aparecem porque a civilização aporta muitas seqüelas, sendo que a mais importante é o "sentimento de culpa". Impossível é, neste momento, olvidar Nietzsche cuja escavação genealógica sobre a moral se ocupou, em boa medida, em retomar a "longa história" dos conceitos de "responsabilidade" e "consciência", para depois passar pela "má consciência", a “culpa". Para Freud, o sentimento de culpa ativado pelo avanço da civilização implicou perda de felicidade e, se isto é verdade, gerou os vingativos homens de ressentimento que, como Dühring, querem ver infelizes os felizes homens responsáveis pelo seu (nosso) futuro. Sentimento de culpa e consciência, portanto, conformam para Freud uma relação explicativa que desemboca na verificação de que a neurose dos indivíduos se atribui a um sentimento de culpa inconsciente. O sentimento de culpa não sendo percebido aparece como mal-estar, e sendo a consciência função do superego este não desativa aquele sentimento, permanecendo a severidade escondida pelo inconsciente.

No desiderato de ajustar as relações entre os homens, a civilização gerou mecanismos dentro dos quais se encontra a relação ética. Muito interessante é notar que Freud não afasta a dimensão relacional da ética dentro do contexto do processo civilizatório. A ética, então, não fica restrita a um problema de intra-relacionamento do homem consigo mesmo, mas também como forma de se comunicar com os outros. É óbvio que o intento freudiano, aqui, é o de fazer uma crítica ao mandamento "Ama a teu próximo como a ti mesmo", o qual "constitui a defesa mais forte contra a agressividade humana e um excelente exemplo dos procedimentos não psicológicos do superego cultural" (FREUD, 1974, p. 168). A partir deste trecho, podemos perceber a preocupação de Freud com os impulsos agressivos dos homens que, em última instância, resultam da frustração degringolada pelo sentimento de culpa. E assim chegamos ao ponto em que desejávamos: amar a todo próximo como a si mesmo é pauta impossível de ser cumprida, revelando-se como infelicidade civilizacional maior que a gerada pela própria agressividade. E é ponteiro o tiro de Freud:

acho também bastante certo que, nesse sentido, uma mudança real nas relações dos seres humanos com a propriedade seria de muito mais ajuda do que quaisquer ordens éticas; mas o reconhecimento desse fato entre os socialistas foi obscurecido, e tornado inútil para fins práticos, por uma nova e idealista concepção equivocada da natureza humana (FREUD, 1974, p. 168). 
Notemos que na asserção de Freud houve uma preocupação, por parte dele, em não atribuir a Marx ou ao marxismo - como especificação do socialismo/comunismo - a noção de homem bom por natureza. Talvez tal prudência se deva ao fato de Freud não ter lido a obra de Marx ou por não o considerar um teórico tão representativo que merecesse ser lembrado, mas o fato é que não citou, apesar de aparentemente sua tradição crítica estar ali consignada. Cremos que o vacilo de Freud - se é que assim podemos nos referir a este ato se deveu, no entanto, à impossibilidade de extrair de Marx esta observação, ainda que não seja nem um pouco impossível retirá-la de alguns prosélitos seus popularizadores.

Muitas poderiam ser as passagens que desmentissem o mito do homem bom, em Marx, assim como em Freud há muito material para desmentir o mito do homem mau. Bastaria lembrar a célebre "Introdução de 1843” para reavivá-lo: “o homem não é um ser abstrato, acocorado fora do mundo. O homem é o mundo do homem, o Estado, a sociedade" MARX, 2005b, p. 145). Definitivamente, deve ser reconhecido que a reflexão de Marx não se ocupa mais atentamente da subjetividade humana, todavia, ela não está emersa num jogo determinista que a torna irresponsável pelo mundo que o homem tem. O homem é seu mundo, sua civilização e, assim sendo, ele o cria numa relação continuamente dialética. Diríamos mais: a subjetividade marxiana se apresenta coletivamente, como sendo a potencialidade de cada um como contributo às necessidades de todos.

Em um excerto de "O 18 brumário de Luís Bonaparte", pensamos restar esclarecido de forma mais eficaz esse entendimento. Diz-nos - pincelando as distinções entre as revoluções burguesas e as proletárias durante o século XIX, e após pintar o quadro dramático e avassalador das primeiras:

as revoluções proletárias, como as do século XIX, se criticam constantemente a si próprias, interrompem continuamente seu curso, voltam ao que parecia resolvido para recomeçá-lo outra vez, escarnecem com impiedosa consciência as deficiências, fraquezas e misérias de seus primeiros esforços (MARX, 1978, p. 332).

enfim, enfrentam o turbilhão da realidade e todas as suas contradições. Se fôssemos seguir Benjamin, um dos grandes intérpretes do marxismo que não se rendeu à vulgata, diríamos com ele: "todos os que até hoje venceram participam do cortejo triunfal, em que os dominadores de hoje espezinham os corpos dos que estão prostrados no chão" (BENJAMIN, 1987, p. 225). 
Assim, parece-nos justificado o porquê de tomarmos as observações de Freud como não destinadas a Marx especificamente, mas sim à plêiade daqueles que comungavam do ideário socialista/comunista (que não tem só nos adeptos de Marx a sua base teórica) e que se diferençavam pelo fato de acreditarem que "o homem é inteiramente bom e bem disposto para com seu próximo, mas a instituição da propriedade privada corrompeu-lhe a natureza" (FREUD, 1974, p. 134). ${ }^{4}$

Sem entrar no mérito do estatuto que tem a propriedade privada em Marx - se inaugura a opressão social ou se um tipo determinado de opressão social, ainda que nunca inaugure a maldade do homem, pois isto pressuporia a sua bondade natural -, valhamo-nos novamente do autor para nos aproximarmos de argumento já referido - o estado de direito como estado de exceção (desde Nietzsche). Na mesma análise de Marx, escrita em 1852, sobre a dita "segunda revolução francesa", encontramos a seguinte prédica:

\begin{abstract}
enquanto o domínio da classe burguesa não se tivesse organizado completamente, enquanto não tivesse adquirido sua pura expressão política, o antagonismo das outras classes não podia, igualmente, mostrar-se em sua forma pura, e onde aparecia não podia assumir o aspecto perigoso que converte toda luta contra o poder do Estado em uma luta contra o capital (MARX, 1978, p. 360).
\end{abstract}

A forma pura da negação do estado é a própria negação do capital. O puro-não se mostra visível novamente. Neste sentido, a fórmula nietzscheana que faz equivaler, em última razão, estado de direito a estado de exceção, ganha novo vigor se entendermos este estado de direito-que-é-exceção como o próprio capital. Não se trata, de nossa parte, de simplificações que reduzem o estado ao poder da classe dominante, mas sim de entendê-lo como símbolo, por isso mesmo contraditório, contra o que se luta.

Ao revisar o estado da arte - e, a um só tempo, reinaugurá-lo - do estado de exceção, Agamben rememora uma luta de gigantes, travada entre Walter Benjamin e Carl Schmitt. É uma pugna que tem por objeto um vazio, a anômica violência pura, constituindo-se em um verdadeiro dossiê esotérico que se inicia com o texto de Benjamin sobre a "Crítica da violência - Crítica do poder”, de 1921. No ensaio, aparece a violência pura (também chamada de divina ou revolucionária), uma tal que esteja fora do direito, ainda que este não a possa tolerar estando fora. É uma violência que não põe nem conserva mas depõe o direito, inaugurando uma nova época histórica. Eis a última oração do texto de Benjamin: 
deve ser rejeitado, porém, todo poder mítico, o poder instituinte do direito, que pode ser chamado de um poder que o homem põe. Igualmente vil é também o poder mantenedor do direito, o poder administrado que lhe serve. O poder divino, que é insígnia e chancela, jamais um meio de execução sagrada, pode ser chamado de um poder de que Deus dispõe (BENJAMIN, 1986, p. 175). ${ }^{5}$

Como resposta a Benjamin, a obra "Teologia política" aparece, trazendo Schmitt a violência pura e anômica para o contexto jurídico. $\mathrm{O}$ estado de exceção é, para ele, o espaço benjaminiano da violência pura, a qual se incluiria no direito por sua exclusão, como atesta sua mais que repetida frase inicial do livro: "soberano é quem decide sobre o estado de exceção" (SCHMITT, 2006, p. 7). Schmitt ainda substituiria sua anterior distinção entre poderes constituinte e constituído pelo conceito de decisão, para fugir à distinção análoga de Benjamin entre violência fundante e conservadora do direito, bem como para respondê-lo. Assim, a violência soberana, do primeiro, corresponde à violência pura do último, com a diferença de que para aquele a soberania era a decisão extrema, enquanto que para este seria o lugar da indecidibilidade última dos problemas jurídicos: “é impossível 'decidir' qualquer problema jurídico" (BENAJMIN, 1986, p. 171). Novo momento do debate é a descrição do soberano barroco, por Benjamin, como resposta à teoria da soberania de Schmitt, a partir da discussão sobre o estado de exceção: o soberano deve excluir (e não decidir sobre) o estado de exceção da ordem jurídica. Eis aí uma verdadeira teoria da indecisão soberana. Sua crítica avança até a distinção entre norma e realização, mencionando ser uma "distância que nenhuma decisão é capaz de preencher" (AGAMBEN, 2007a, p. 88). O paradigma do estado de exceção, assim, sai da esfera do milagre e vai para o da catástrofe, uma zona de absoluta indeterminação entre anomia e direito (e não uma articulação entre ambos).

Contudo, é na oitava tese sobre o conceito de história que o dossiê esotérico atinge seu momento decisivo. Ali, o estado de exceção irrompe como regra, pondo em apuros a teoria de Schmitt. A oitava tese distingue entre estado de exceção e estado de exceção efetivo, excluindo a possibilidade de um estado de exceção fictício, que em Schmitt significa o estado de exceção que se pretende regulamentar por lei. O estado de exceção efetivo é aquele no qual se vive, indiscernível da regra, mostrando uma violência sem roupagem jurídica:

a tradição dos oprimidos nos ensina que o "estado de exceção" em que vivemos é na verdade a regra geral. Precisamos construir um conceito de história que corresponda a essa verdade. Nesse momento, perceberemos que nossa tarefa é originar um verdadeiro estado de exceção (BENJAMIN, 1987, p. 226). 
A discussão então se dá em torno de uma zona de anomia, a qual ou se relaciona com ou se liberta do direito. No fundo, trata-se da relação entre violência e direito. O que está em jogo é um espaço vazio - a anomia ou o ser puro. Assim, pode-se entender que a violência pura não é figura originária do agir humano, mas o que está em jogo na disputa sobre o estado de exceção. E, dessarte, o puro-não incrustado no debate entre Freud e Marx ganha novíssimo fôlego. A violência pura é um termo técnico essencial para a compreensão de Benjamin. Para ele, a pureza adquire uma concepção relacional e não substancial. Portanto, a violência pura significa a relação da violência com o direito, não sendo mero meio relativo a fins, mas meio puro, medialidade sem fins. Eis que a violência pura possui uma relação com sua própria medialidade, expondo e cortando o elo entre direito e violência.

A conclusão (inconclusa) de Agamben sobre esta disputa redunda em uma ousada profanação do direito, à Kafka, em que ele "não é mais praticado mas apenas estudado", ou seja, é um novo direto, à Foucault, "que não tem mais força nem aplicação" (AGAMBEN, 2007a, p. 97). Não seria ele a justiça mesma mas a chave que levaria a ela. Contrapõe-se, pois, um novo uso do direito à força-de-lei; um novo uso que o liberte de seu próprio valor. E "essa libertação é a tarefa do estudo, ou do jogo" (AGAMBEN, 2007a, p. 98). Se a força-de-lei não quer deixar desativar o direito, é preciso brincar e desligar os seus fios, abrindo espaço para "uma nova relação com as coisas: a apropriação da irrealidade" (AGAMBEN, 2007b, p. 85).

\section{A negação da vida e a vida sacra}

Em Oliverio Girondo, sem dúvida, operou a unidade na dualidade própria do pensamento colonial e, em específico, do latino-americano. O imperial e o colonial se unem, assim como o ficcional e o metaficcional. Para Raúl Antelo, tal "unidade na dualidade" poderia ser considerada como uma espécie "de complemento de las alegorías benjaminianas del inconsciente colonial” (ANTELO, 1999, p. XXX). Curiosa esta aproximação de Girondo e Benjamin feita pelo crítico, porque ela mesma aparece como esta unidade dual na voz do exegeta coetâneo. Não só porque Benjamin se interessou pela cultura maia e asteca (e Girondo, como todo bom latino-americano de ontem e de hoje, pela arte européia) é que eles se tangenciam. Também, Girondo fez de sua experiência de viajante uma verdadeira poética própria, da mesma forma que Benjamin extraiu do viajar uma teoria baseada na experiência, “como extracción del límite o como saber arrancado a lo inerme" (ANTELO, 1999, p. LIX). R. Fac. Dir. UFG, v. 38, n. 2, p. 121 - 148, jul. /dez. 2014 
Mais uma vez é a própria comparação que instaura a unidade na dualidade, pois, profanatoriamente, o colonial é o poético ficcional e o imperial é o teórico metaficcional. E vice-versa.

O que resta, porém, do poeta do puro-não? Segundo um seu aforismo, “¡el Arte es el peor enemigo del arte! ... un fetiche ante el que ofician, arrodillados, quienes no son artistas" (GIRONDO, 1999, p. 68). Segundo Adorno, “depois de Auschwitz não se pode escrever uma poesia" (ADORNO apud AGAMBEN, 2008, p. 86); e justamente por isso, pensamos nós, talvez seja possível entender porque Girondo é o último escritor - Auschwitz, para ele, não é um local, mas uma relação: “el sacudimiento que estremece a Europa repercute en nosotros con tal intensidad, que puede vaticinarse, sin embargo, un clima muy propicio a un verdadero despertar". Em sua voz pouco socialista, o corolário que segue pode até estranhar: "ha llegado el momento de liberarnos, de una vez por todas, de la opresión económica, casi secular, que nos asfixia" (GIRONDO, 1999, p. 329). Acontece que o uno se converte em duplicidade.

O puro-não que o campo de concentração engendra é nauseante. Experiência vivida no centro do mundo, pensou-se que teria sido a última, porque o próprio filho primogênito da modernidade - o continente europeu - houvera sido dado em sacrifício para redimir e salvar a alma de todos os demais. Mas não, puramente não. Nem holocausto nem crucificação: o que se deu foi a barbárie inadjetivável, mais uma, aliás, ainda que a mais "concentrada" de todas. Só a conquista da América lhe seria comparável. Fazendo-se uma macabra matemática, podemos aquilatar a carnificina: na América, em cerca de cem anos, cem milhões de indígenas foram exterminados; nos campos nazistas, em cerca de seis anos, seis milhões de judeus. Como saldo, um milhão de cadáveres por ano. Concordamos, portanto, com a atenção dada ao surgimento de um paradigma moderno do campo; mas não nos esquecemos de lembrar outros vencidos, desde nossa América, e seu correlato paradigma do encobrimento.

Aqui, tornitroa a afirmação de Benjamin: "os que num momento dado dominam são os herdeiros de todos os que venceram antes" (BENJAMIN, 1987, p. 225). Assim é que Auschwitz deve sua existência a Cortez, Pizarro e Raposo Tavares, assim como o neoliberalismo que hoje campeia tem uma dívida de morte para com a fábrica de cadáveres da ulica Miła (que quer dizer, em polonês, rua Bonita, a rua central do campo de Auschwitz). 
A história dos vencedores não dá trégua; sua herança é maldita. Mais que ilustrativo seria lembrar, hoje, algumas outras proezas, algumas outras "vitórias". Em testemunho que não se pode desprezar, tomamos notícia de que ainda hoje é impossível escrever poesia, sendo necessário relembrar os velhos versos para nos rebelarmos. Leandro Gaspar Scalabrin, advogado do Movimentos dos Trabalhadores Rurais Sem-Terra (MST), é uma das personagens deste testemunho, testemunho que precisa da voz dos que não são as verdadeiras testemunhas para se fazer ouvir. São suas as palavras que seguem:

\begin{abstract}
a transformação do "princípio de segurança" no eixo fundamental dos direitos humanos, fato generalizado de forma sem precedentes na história recente da humanidade, em substituição da "declaração do estado de exceção", com o pretexto de combate ao terrorismo, também pode ser verificada no Brasil, com especial ênfase no Rio Grande do Sul (RS), nos anos de 2007 e 2008, onde movimentos sociais opositores do modelo neoliberal do governo estadual ou apenas do modelo neodesenvolvimentista do governo federal, são qualificados como terroristas (SCALABRIN, 2008, p. 3).
\end{abstract}

O texto é motivado pelo ajuizamento de ação civil pública, por conta do Ministério Público do Estado do Rio Grande do Sul (MPE/RS), "contra” o MST, "sociedade de fato dotada de personalidade judiciária" (RIO GRANDE DO SUL, 2008b, p. 1), em prol de que se desocupe, em região determinada do estado gaúcho, imóveis que estejam sendo utilizados pelo referido movimento para os fins de suas reivindicações, sob o pretexto de que está desenvolvendo atividades ilícitas contra a segurança nacional. Cabe notar, desde logo, que a própria forma inscrita na peça inicial revela a exceção que informa a ação: trata-se de postular "contra", e não "em face de", como se fosse a primeira dobra do sino que anuncia o combate sem volta, a guerra contra a subversão. E ainda mais: o apelo ao decisionismo judiciário quando se aceita uma construção pretória como sendo realmente existente: a suposta "personalidade judiciária" (que se diferencia da "personalidade jurídica", por fazer caso das formalidades de registro burocrático), figura construída pela própria magistratura para se dar legitimidade passiva ao MST, dentro do judiciário.

No terceiro volume da sua série intitulada "Homo sacer", Giorgio Agamben reabre o debate acerca de Auschwitz, não para aperfeiçoar a narrativa histórica sobre o nazismo, mas para desvendar seu significado ético-político. Se para Benjamin uma causa só se torna "violência", se "interfere em relações éticas" (BENAJMIN, 1986, p. 160), para Agamben, são estas que saem inviabilizadas depois dos campos de concentração. Neles, 
quedam as "verdadeiras" testemunhas, impossibilitando o acesso histórico ao que se viveu, pelo simples fato de que quem morreu é que era a testemunha. Em outras palavras, "as 'verdadeiras' testemunhas, as 'testemunhas integrais' são as que não testemunharam, nem teriam podido fazê-lo", quer dizer, "os que 'tocaram o fundo', os muçulmanos, os submersos" (AGAMBEN, 2008, p. 43) não falam e é assim que os sobreviventes testemunham por eles, delegadamente.

Uma explicação é necessária. Agamben se refere ao "muçulmano" como a verdadeira testemunha que não pode testemunhar. Em verdade, uma não-testemunha. É o "hirto inósseo innão no uníssolo amódulo", se profanarmos o verso de Girondo. Transformado em não-homem, o "muçulmano" conserva algumas características humanas, mas se transmuta em um ser inferior, desprendido do mundo, fora de sua própria órbita. Em última instância, o "muçulmano" era o judeu ${ }^{6}$ que se desenganava a si mesmo, punha-se a par daquele mundo e sofria enormemente com os maus tratos dos soldados alemães. "Sem som sem sexo nem órbita", o "muçulmano" rastejava, quando não era mesmo arrastado, para a câmara de gás e nada mais.

O depoimento do advogado do MST revela, guardadas as mais que devidas proporções, esta relação, uma vez que viveu minimamente sua exceção, desde o começo das ações do MPE/RS contra o MST, em 2007, quando lhe fora negada "vista dos documentos 'sigilosos' usados no processo pelo promotor" (SCALABRIN, 2008, p. 4). O defensor se refere aqui a uma série de documentos elaborados pela Brigada Militar (polícia militar) sulrio-grandense com o intuito de caracterizar o movimento como grupo paramilitar. Estes documentos redundariam na Instrução Operacional no 6-1 (IO6), a qual tem por objetivo conceder "aos Comandantes Regionais da Brigada Militar do RS, o poder de suspender atividades políticas de movimentos sociais" o que significa dizer, "a proibição de realizar atos ou protestos em órgãos públicos e áreas privadas", emprego "da medida de segurança de 'liberdade vigiada' consistente na identificação de lideranças de movimentos sociais”, bem como “ainda, 'proibição de freqüentar determinados lugares', mesmo sem ordem judicial para tanto ou sem queixa crime do proprietário de área privada" (SCALABRIN, 2008, p. 7).

Ressalte-se que documento jurídico de tamanha relevância é considerado do âmbito do mero expediente interno da corporação e não se encontra disponível para consulta na sua página virtual. Logo se percebe que a tão aclamada defesa da democracia resulta em R. Fac. Dir. UFG, v. 38, n. 2, p. 121 - 148, jul. /dez. 2014 


\section{RICARDO PRESTES PAZELLO}

pura não-democracia, que começa por desdizer a constituição, a qual se pretende proteger, tendo na comparação de Scalabrin uma medonhamente feliz analogia: depois do AI-5, a IO-6. A IO-6, ainda, estabelece quatro situações em que a ação de Sonderkommando da Brigada deve ser levada em consideração no tangente à mobilização dos movimentos sociais, em especial os do campo: situação de normalidade (a qual exige cadastro de todos os militantes e apoiadores, bem como imóveis, públicos ou privados, possíveis alvos de “invasão”); situação de eminente ocupação (a exigir formação de barreiras policiais para impedir as ocupações, bem como a decisão sobre a existência ou não do "ânimo de invasão"); situação de ocupação concretizada (demandando o isolamento da área ocupada e o gerenciamento das negociações para dar cabo ao acampamento, independentemente de ordem judicial ou de pedido do proprietário); e situação de execução do mandado para ação de retirada dos invasores (implicando revista e identificação criminal, para os casos de desocupação "voluntária", e afora isto a apreensão dos meios de transporte utilizados, para os casos de "reintegração compulsória"). Vivendo, pois, sob o paradigma político do estado de exceção, conseqüência moderna do biopoder, os militantes do MST podem ser tidos como verdadeira "vida sacra" que, nas palavras de Agamben, representa "a vida insacrificável e, todavia, matável" (AGAMBEN, 2007c, p. 90).

A ação civil pública já referida explora todas essas nuanças para pôr-se "contra" o MST e, sem recalques, levanta inclusive a lei de crimes contra a segurança nacional (lei 7.170/1983) como seu fundamento. Argumentando a partir de boletins de ocorrência ou de atendimento, suscita cerca de vinte tipos penais nos quais se enquadrariam os integrantes do MST, sendo três deles oriundos da lei de segurança nacional. ${ }^{7}$ Espanta-nos, assim, a falácia do discurso protetor da constituição quando tantas garantias e direitos fundamentais restam achincalhados.

Com todo esse quadro já pintado, não surpreende que também o judiciário tenha dado razão à denúncia do MPE/RS. A título de esclarecimento, sumariemos os "pedidos" constantes na ação civil pública: além de as desocupações dos imóveis especificados - que na verdade tinham os integrantes do MST como arrendatários, portanto, em relação jurídica totalmente lícita -, pede-se expedição de mandado inibitório para que os réus não pratiquem, nos mesmos imóveis, atos tais quais formação de acampamentos, utilização dos imóveis, reunião de sem-terras, "aliciamento" ou "arregimentação" de militantes para o movimento, 
propaganda ou representação do MST, marchas e manifestações. Acresçamos o pedido de liminar para a desocupação, o que foi prontamente atendido pelo juiz de Carazinho.

A expressa inconstitucionalidade do pedido só pode ser afastada se se aceitar a retórica da lei de segurança nacional como lastro da ação. De qualquer forma, o juízo de primeira instância escusou-se de tão importante argumento para enfrentar o problema proposto pelo MPE/RS. Contudo, tangenciou-o, ao dizer - e, literalmente, sublinhar - que seu entendimento era de que "os acampamentos localizados nas imediações da Fazenda Coqueiros tornaram-se sementeiras de conflitos" (RIO GRANDE DO SUL, 2008a, p. 6). O juiz ainda fundamenta sua convicção expressando que o MST está a afrontar o estado de direito e, por isso, torna possível suspender a constituição em nome da manutenção do sistema, já que o MST abala "as expectativas da comunidade". O estado de direito mostra-se, nietzscheanamente, como verdadeiro estado de exceção. Talvez o magistrado esteja a aplicar as lições de um superior seu, o ministro do STF Eros Roberto Grau, cujo ensinamento parte de Schmitt e retorce Agamben:

\footnotetext{
insisto em que a exceção não está inserida para além do ordenamento, senão no seu interior. Pois o estado de exceção é uma zona de indiferença entre o caos e o estado da normalidade, zona de indiferença não obstante capturada pelo direito. De sorte que não é a exceção que se subtrai à norma, mas ela que, suspendendo-se, dá lugar à exceção - apenas desse modo ela se constitui como regra, mantendo-se em relação com a exceção (GRAU, 2006, p. XI). ${ }^{8}$
}

Portanto, o choque agrário gaúcho é reduzido, pela liminar, a uma "sementeira de conflitos" e a uma violação do estado de direito. Ainda que o juiz reconheça a legitimidade dos protestos dos sem-terra por conta da inexistência de um reforma agrária "decente" - que o estado de direito brasileiro erigiu como sua própria suspensão, excepcionando-a - concede "fumaça de bom direito" ao Ministério Público estadual para desabrigar os campesinos acampados nas proximidades da Fazenda Coqueiros. Frente a isto ele mesmo se pergunta: “para onde irão os acampados, uma vez efetivada a presente liminar?”; e sua resposta subverte a lógica do bom senso: "não me competiria e, creio, não compita ao Poder Judiciário a definição de local para onde serão removidos os acampados" (RIO GRANDE DO SUL, 2008a, p. 23). A única coisa que resta é o não, inóvulo e nonato, instaurado pelo estado de direito-que-é-exceção que faz da região de Carazinho uma zona de trânsito vedado, Gaza brasileira, tendo por carta magna a IO6. 


\section{RICARDO PRESTES PAZELLO}

Insta-nos, ainda a este respeito, notar que a peça inicial da ação civil pública tem por fulcro a revisão do histórico do problema agrário, no qual se insere o surgimento de movimentos campesinos como o MST. Parece-nos importante ressaltar qual foi o seu ponto de partida: "a questão agrária tornou-se um fator que contribuiu para o movimento políticomilitar de 1964" (RIO GRANDE DO SUL, 2008b, p. 4). A frase, assustadoramente, parece querer justificar o regime ditatorial perpetrado no Brasil pelos militares apoiados por forças ocultas internas e, principalmente, externas. A partir daí, toda a argumentação é válida na petição. Não surpreende, portanto, que se valha inclusive de discussão recente acerca do caráter do MST, mas só fazendo uso de uma das partes da polêmica. Trata-se do texto de Zander Navarro que faz uma dura crítica ao movimento em tela, partindo da idéia de que "a prática política do Movimento, ao longo dos anos, obedecendo à ortodoxa preferência leninista de sua direção principal, tem sido essencialmente não-democrática" (NAVARRO, 2005, p. 216). Este é o grande argumento do autor para criticar a postura do MST: antidemocrático. Para ele, democracia significa um jogo pautado pela "possibilidade de irrestrita materialização de formas de representação que, autonomamente, estruturem seus interesses e os disputem abertamente no campo das lutas políticas sem, contudo, deixar de assumir suas responsabilidades" (NAVARRO, 2005, p. 218). Certamente, sua noção de jogo não se aproxima em nada da profanação proposta por Agamben, para quem é preciso devolver as coisas sacralizadas ao uso quotidiano dos homens. A democracia como "possibilidade irrestrita de representação" não passa de uma glasnost às avessas em que o estado de exceção passa a controlar aquilo que se opõe a ele. A representação a todo custo nada mais é que o improfanável. Direito não é privilégio e não há justificativa alguma para se corroborar a antidemocracia brasileira, no que pertine à distribuição de riquezas e, em especial, de terras.

O texto inicial da ação civil pública, ainda, não se interessou por fazer registrar o restante da polêmica. O texto de Navarro é respondido por Horácio Martins de Carvalho, o qual classifica entre os opositores históricos do movimento, além de as classes dominantes nacionais, os governos que têm ocupado a direção dos executivos federal e estaduais, as forças paramilitares, as agências multilaterais de financiamento, também "amplos setores da intelectualidade de centro-esquerda do país" que abdicaram de sua postura crítica frente ao estado de coisas, por decorrência de um desencanto pessoal ou da cooptação pelas classes dominantes. Não sem desconsiderar as contradições internas do movimento, Carvalho aponta para a tentativa de se estabelecer uma democracia interna, baseada na "superação pelo MST das formas corporativas e dos mecanismos liberais da representação política" (CARVALHO, R. Fac. Dir. UFG, v. 38, n. 2, p. 121 - 148, jul. /dez. 2014 
2005, p. 250), ou seja, nas ações diretas e na constatação de que "cada instância, desde o assentamento, passando pelas direções regionais, estaduais e nacional, possui autonomia relativa" (CARVALHO, 2005, p. 247). A polêmica ainda teria uma tréplica de Navarro, a qual, no entanto, não faz mais que repetir, além de maldizer seu opositor, os argumentos do primeiro texto.

Outra interessante, para dizer o mínimo, fundamentação apresentada na inicial da ação civil pública é a que tem o texto de Denis Rosenfield como âncora. Incluída no contexto de caracterização do MST como "um verdadeiro Estado paralelo", com "total desprezo daquele movimento em relação aos poderes constituídos, em especial no que diz respeito ao Poder Judiciário", apresentando sérios "riscos ao estado democrático de direito" (RIO GRANDE DO SUL, 2008b, p. 54, 112 e 122), tal fundamentação se farta em demonstrar que o MST possui "ideologia de cunho marxista vulgar, revolucionária”, baseia-se em Gramsci, "com uso explícito de seus conceitos" e reivindica "uma reforma agrária de tipo socialista" (ROSENFIELD, 2006, p. 305, 329 e 374). Ela serve aqui para ilustrar o quão profunda foi a exposição de motivos do MPE/RS, valendo-se de Rosenfield que tem por grande intuito retirar da ideologia do Partido dos Trabalhadores (PT), das cartilhas do MST e dos textos produzidos por membros das igrejas católica e luterana que integraram a vertente da teologia da libertação, uma equivalência entre Comissão Pastoral da Terra (CPT) e MST: “é o ódio que orienta a ação das invasões realizadas pela CPT e pelo MST” (ROSENFIELD, 2006, p. 289).

Mais do que qualquer outra coisa, aqui fica patente que se esposam, consciente ou inconscientemente, as idéias de Carl Schmitt sobre a política, ainda que de uma maneira bastante simplificada. Rosenfield mesmo dedica um capítulo inteiro, dos quatro de seu livro, ao que segundo ele é o "teológico-político", significando a já aduzida equivalência entre CPT e MST, a partir do casamento entre teologia e marxismo, ou seja, teologia da libertação. Mais do que isso, porém, cabe a crítica do teólogo leigo e economista alemão Franz Hinkelammert, radicado na América Latina desde a década de 1970 quando fez parte do governo Allende, ao conceito de política, alicerçado em Schmitt:

la actualidad de Carl Schmitt radica en la transformación de la relación amigoenemigo en una relación sistema social-enemigo. La relación amigo-adversario o amigo-opositor al interior del sistema es vista como una relación de lucha, amenazada por el enemigo. Es la posibilidad de lucha la que es defendida contra un 
enemigo que es enemigo de la posibilidad de luchar. Por eso el enemigo es siempre utopista y, a la vez, pacifista (HINKELAMMERT, 1987, p. 130).

Dessa forma, a crença de Schmitt em estar descrevendo (e não prescrevendo) a política como relação amigo-inimigo, vale dizer, constatando-a como um fato empírico, é herdada, só que transmutando-se do âmbito da guerra para o do mercado. A recepção de Schmitt se daria, por conseguinte, pelo neoliberalismo e o campo de batalha seria o mercado. Qualquer coisa que o contradisser (como, por exemplo, a luta pela terra) torná-lo-á passível de inimizade: “está em avançado estágio de execução no Brasil um verdadeiro movimento revolucionário, de inspiração marxista-leninista, tendo como exemplo o modelo revolucionário cubano e sob orientação de operadores estrangeiros, tais como as FARC" (RIO GRANDE DO SUL, 2008b, p. 116-117).

Eis, portanto, a concreção da vida sacra na voz das personagens principais do processo judicial sob a forma de ação civil pública, no Rio Grande do Sul. Magistratura, Ministério Público e defesa perfilam ante nossos olhos como que materializando o estado de exceção e a vida nua que lhe é inerente. ${ }^{9}$ Devemos, agora, procurar entender esta relação ético-política, a fim de resguardarmos a "geração que vem" dos "impuros zeros nãos que nãoam nãoam nãoam”. Se não podemos, hoje, envidar o efetivo estado de exceção ao estado de exceção "em que vivemos" (como já há tempos encorajou Benjamin, em sua tese 8), que ao menos não calemos diante do estado de direito-que-é-exceção.

\section{Ao modo de conclusão: escatologia da história renegada}

Partimos do puro-não de Girondo. Nele pudemos perceber a negação da vida, seja como estratégia política, seja como relação ética (entre homens). O estado de exceção, e seus profetas, bem o relataram.

Homens felizes, "muçulmanos" ou militantes sem-terra, todos se vêem sob o signo do alvedrio, do estado de exceção. Mormente, hoje, em que a continuidade da barbárie é a barbárie à enésima potência (e, se continuar, só poderá aumentar este infinito potencial), a vida sacra se revela como regra geral. Ainda que a vida (ao lado da propriedade privada) seja princípio basilar da ordem constitucional do ocidente, aceita-se fazer dela alvo da biopolítica e, assim, torná-la em homo sacer. Este homem de vida sacra possui algo parecido com vida, 
uma vida, por decorrência, que não merece viver. O exemplo da autorização nazista da eutanásia e da criação da figura jurídica da "vida indigna de ser vivida" é eloqüente. $\mathrm{Na}$ verdade, o programa hitlerista punha em questão o exercício do poder soberano, pois "na biopolítica moderna, soberano é aquele que decide sobre o valor ou desvalor da vida enquanto tal" (AGAMBEN, 2007c, p. 149).

Como já vimos, soberano é quem decide sobre o estado de exceção e a exceção é a regra. A criação de uma zona de isolamento, em que os integrantes do MST não podem sequer se aproximar, mesmo tendo relações jurídicas lícitas, como um simples contrato de arrendamento, remete-nos a isto. Contudo, assim como a vida sacra é ambivalente (insacrificável mas matável a qualquer tempo), também o é a figura do soberano. Bem o demonstra o conceito de "bando", em Agamben.

A relação de bando é fundamentalmente ambígua, sendo "essencialmente o poder de remeter algo a si mesmo, ou seja, o poder de manter-se em relação com um irrelato pressuposto" (AGAMBEN, 2007c, p. 116). Trata-se de abandonar-se a si mesmo, bem como de dar uma banda pelo mundo. Enfim, “o bando é propriamente a força, simultaneamente atrativa e repulsiva, que liga os dois pólos da exceção soberana: a vida nua e o poder, o homo sacer e o soberano" (AGAMBEN, 2007c, p. 117).

Significativo é trazer à baila personagem histórica brasileira tão mistificada como a do "bandeirante", à luz desta interpretação. Resgatemos a etimologia da palavra "bandeira", que é de onde surge o termo "bandeirante": vem "do gótico bandwa "sinal, estandarte", e "o nome, dado no Brasil às caravanas em marcha pelos sertões, deve ser uma reminiscência das companhias de assalto que outrora, na metrópole, eram incumbidas de reconhecimentos arriscados e empresas temerárias” (NASCENTES, 1966, p. 86). Assim, o bandoleiro vira soberano e o bandido, bandeirante. Não é à-toa que o juiz de Carazinho sentencia, depois de aceitar algum tipo de protesto - os legítimos - para que funcionem como mecanismo de pressão: "desse, digamos, juízo de admissibilidade a certa bandalheira, a certos rompimentos da ordem, não se pode inferir, todavia, permissividade com a violência ignóbil, o vandalismo desenfreado ou mesmo a estupidez consentida" (RIO GRANDE DO SUL, 2008a, p. 10). Destacaríamos da frase a expressão "bandalheira", que nos aproxima do bando agambeniano, possibilitando-nos perguntar: de que "bandalheira" se fala? Da fome e da falta de terra para muitos? Do estado de exceção?

R. Fac. Dir. UFG, v. 38, n. 2, p. 121 - 148, jul. /dez. 2014

ISSN 0101-7187 
Fica, pois bem, assentado o que é a soberania: "estrutura originária na qual o direito se refere à vida e a inclui em si através da própria suspensão" (AGAMBEN, 2007c, p. 35). Sejam bandoleiros ou bandeirantes, o soberano se pretende onipotência, só que quanto à vida. E aqui retornamos a Girondo. Sua poética masmedular é histórica, porque apresenta uma estrutura e timbre próprios que devem ser auscultados conforme sua inserção contextual, e é subjetiva, porque enfatiza o seu mundo interno frente ao externo. Para nós, porém, ressalta a qualidade de repetição: aqui está a mediação com a qual queremos lidar.

Repetindo o puro-não - sem o deixar de enfatizar e timbrar -, Girondo mostra-nos sua preocupação. O não é inconfundível com o nada. Um leva ao puro-não; o outro, ao niilismo. Apesar de esta tensão restar marcada na obra do poeta argentino, fazemos sua suprassunção e entendemos o que Agamben pretendeu com seu movimento retro-alimentar de subjetivação e dessubjetivação:

\footnotetext{
possibilidade (pode ser) e contingência (pode não ser) são os operadores da subjetivação, do ponto em que um possível chega à existência, se dá por meio da relação com uma impossibilidade. A impossibilidade, como negação da possibilidade [não (pode ser)], e a necessidade, como negação da contingência [não (pode não ser)], são os operadores da dessubjetivação, da destruição e da destituição do sujeito, ou seja, dos processos que nele estabelecem a divisão entre potência e impotência, entre possível e impossível (AGAMBEN, 2008, p. 148).
}

Desse modo, fica-nos a impressão de que a tensão entre o não e o nada explodem quando o poeta balbucia: "nem eu nem cova nem fosso". O puro-não, exatamente aqui, chega ao fundo de sua própria sepultura e só pode, a partir de então, perceber que no fundo, no eterno fundo, só o poço sem fundo. Por isso, a impressão de Agamben, ao focar o retrato capturado por Sebastião Salgado: "no estúdio onde trabalho, sobre um móvel ao lado da escrivaninha, está a fotografia - aliás, bastante conhecida - do rosto de uma menina brasileira que parece fixar-me severamente, e sei com absoluta certeza que é e será ela a julgar-me, tanto hoje como no último dia" (AGAMBEN, 2007d, p. 29). Sem embargo, é a "geração que vem" a olhar-lhe (e é a menina do MST a interpelar-lhe). Sem compromisso com seu futuro, é o agora do próprio sujeito observado. A fotografia nos exige um gesto - a redenção.

Com o gesto redentor, que é não redentorista (assim como o não não é o nada), aportamos em nosso ponto de chegada. Do puro-não como não, chegamos ao puro-não que se transconsubstancia em sim. O poema é claro: "o não mais nada tudo" é o estado último do R. Fac. Dir. UFG, v. 38, n. 2, p. 121 - 148, jul. /dez. 2014 
puro-não, impulsionando-nos à resistência, aquela profetizada por Benjamin: a resistência é a exceção à exceção, é o não somado ao nada, que pode estar agregado ao tudo ou ser seu antecedente. Em realidade, não é soma que leva a tornar tudo possível, mas um sim qualificado resistentemente, estado de exceção efetivo, negação da negação que nega puramente. Nem tudo é possível, sim; mas não é impossível afirmar a negação da renegação.

Enfim, o puro-não já não pode ser não, porque se lhe torna a própria negação. $\mathrm{O}$ puro-não, no poslodocosmos, só pode ser o sim qualificado, caso contrário negaria a sua própria renegação, não lhe sobrando nada. Ou melhor, só nada. A escatologia, portanto, é o que nos resta.

\section{Referências}

AGAMBEN, Giorgio. Estado de exceção: homo sacer II, 1. Tradução de Iraci D. Poleti. 2 ed. São Paulo: Boitempo, 2007a.

Estâncias: a palavra e o fantasma na cultura ocidental. Tradução de Selvino José Assmann. Belo Horizonte: UFMG, $2007 \mathrm{~b}$.

Homo sacer: o poder soberano e a vida nua I. Tradução de Henrique Burigo. 1 ed. 2 reimp. Belo Horizonte: UFMG, 2007c.

O que resta de Auschwitz: o arquivo e a testemunha (homo sacer III). Tradução de Selvino José Assmann. São Paulo: Boitempo, 2008.

Profanações. Tradução de Selvino José Assmann. São Paulo: Boitempo, 2007d.

ANTELO, Raúl. "Estudio filológico preliminar (papiers collés)”. Em: GIRONDO, Oliverio. Obra completa - Oliverio Girondo: edición crítica. Coordenación de Raúl Antelo. Madrid; Barcelona; Lisboa; París; México; Buenos Aires; São Paulo; Lima; Guatemala; San José; Santiago de Chile: ALLCA XX, 1999, p. XXVII-XC.

BENJAMIN, Walter. "Crítica da violência - Crítica do poder". Em: BOLLE, Willi (org.). Documentos de cultura, documentos de barbárie: escritos escolhidos. Tradução de Celeste H. M. Ribeiro de Sousa São Paulo: Cultrix; EDUSP, 1986, p. 161-175.

."Sobre o conceito da história". Em: . Obras escolhidas - Magia e técnica, arte e política: ensaios sobre literatura e história da cultura. Tradução de Sergio Paulo Rouanet. 3 ed. São Paulo: Brasiliense, vol. 1, 1987, p. 222-232.

CARVALHO, Horácio Martins de. "A emancipação do movimento no movimento de emancipação social continuada (resposta a Zander Navarro)”. Em: SANTOS, Boaventura de Sousa (org.). Produzir para viver: os caminhos da produção não capitalista. 2 ed. Rio de Janeiro: Civilização Brasileira, 2005, p. 233-260.

R. Fac. Dir. UFG, v. 38, n. 2, p. 121 - 148, jul. /dez. 2014

ISSN 0101-7187 
DUSSEL, Enrique Domingo. 20 tesis de política. México, D.F.: Siglo Veintiuno Editores; CREFAL, 2006.

ENGELS, Friedrich. Do socialismo utópico ao socialismo científico. Tradução de Ubiracy A. M. Cintra. São Paulo: Moraes, s. d.

FRAGOSO, Heleno Cláudio. "A nova lei de segurança nacional". Em: Revista jurídica virtual. Brasília: Casa Civil da Presidência da República, vol. 5, n 58, março de 2004, p. 1-7. Disponível em: < http://www.planalto.gov.br/ccivil_03/revista/Rev_58/panteao/Heleno ClaudioFragoso.pdf $>$. Acesso em: $1^{\circ}$ de novembro de 2008.

FREUD, Sigmund. "O mal-estar na civilização". Em: . Edição standard brasileira das obras psicológicas completas de Sigmund Freud. Tradução José Octávio de Aguiar Abreu. Rio de Janeiro: Imago, vol. XXI, 1974, p. 73-171.

GAGNEBIN, Jeanne Marie. “Apresentação”. AGAMBEN, Giorgio. O que resta de Auschwitz: o arquivo e a testemunha (homo sacer III). Tradução de Selvino José Assmann. São Paulo: Boitempo, 2008, p. 9-17.

GIRONDO, Oliverio. Obra completa - Oliverio Girondo: edición crítica. Coordenación de Raúl Antelo. Madrid; Barcelona; Lisboa; París; México; Buenos Aires; São Paulo; Lima; Guatemala; San José; Santiago de Chile: ALLCA XX, 1999.

GRAU, Eros Roberto. “Apresentação”. Em: SCHMITT, Carl. Teologia política. Tradução de Elisete Antoniuk. Belo Horizonte: Del Rey, 2006, p. IX-XIV.

HINKELAMMERT, Franz J. Democracia y totalitarismo. San José: DEI, 1987.

MARX, Karl. A questão judaica. Tradução de Sílvio Donizete Chagas. 5 ed. São Paulo: Centauro, 2005a.

. "Crítica da filosofia do direito de Hegel - Introdução". Em: Crítica da filosofia do direito de Hegel. Tradução de Rubens Enderle e Leonardo de Deus. São Paulo: Boitempo, 2005b, p. 145-156.

. "O 18 Brumário de Luís Bonaparte". Em: . Manuscritos econômico-filosóficos e outros textos escolhidos. Tradução de Leandro Konder. 2 ed. São Paulo: Abril Cultural, 1978, p. 323-404.

; ENGELS, Friedrich. A ideologia alemã: crítica da novíssima filosofia alemã em seus representantes Feuerbach, B. Bauer e Stirner, e do socialismo alemão em seus diferentes profetas. Tradução de Marcelo Backes. Rio de Janeiro: Civilização Brasileira, 2007.

NASCENTES, Antenor. Dicionário etimológico resumido. Rio de Janeiro: Instituto Nacional do Livro, 1966.

NAVARRO, Zander. “'Mobilização sem emancipação' - as lutas sociais dos sem-terra no Brasil”. Em: SANTOS, Boaventura de Sousa (org.). Produzir para viver: os caminhos da produção não capitalista. 2 ed. Rio de Janeiro: Civilização Brasileira, 2005, p. 189-232. 
NIETZSCHE, Friedrich. Genealogia da moral: uma polêmica. Tradução de Paulo César de Souza. 9 reimp. São Paulo: Companhia das Letras, 2006.

NOBILE, Beatriz de. El acto experimental: Oliverio Girondo y las tensiones del lenguaje. Buenos Aires: Losada, 1972.

RIO GRANDE DO SUL. Juízo de Direito. Decisão liminar n. 009/1.08.0002730-7. Juiz de Direito: Orlando Faccini Neto. Carazinho, 16 de junho de 2008. Disponível em: < http://www.tj.rs.gov.br/site_php/noticias/mostranoticia.php?assunto=1\&categoria=1\&item=6 6333 >. Acesso em: 27 de agosto de 2008a.

Ministério Público do Estado. Ação civil pública, com pedido de antecipação de tutela. Promotor de Justiça: Benhur Biancon Junior e outros. Carazinho, 11 de junho de 2008. Disponível em: < http://www.mp.rs.gov.br/areas/imprensa/anexos_noticias/inicial acampamentos.pdf $>$. Acesso em: 27 de agosto de 2008b.

ROSENFIELD, Denis Lerrer. A democracia ameaçada: o MST, o teológico-político e a liberdade. 2 ed. Rio de Janeiro: Topbooks; Brasília: Instituto Tancredo Neves de Estudos Políticos, Econômicos e Sociais, 2006.

SCALABRIN, Leandro Gaspar. Estado de exceção no Rio Grande do Sul. Mimeo, 2008. SCHMITT, Carl. Teologia política. Tradução de Elisete Antoniuk. Belo Horizonte: Del Rey, 2006.

\footnotetext{
${ }^{1}$ Há uma tradução do poema para o português nesta mesma edição, de Augusto de Campos, intitulando-o de "O puro não": “O não/ O não inóvulo/ O não nonato/ O não innão/ O não poslodocosmos de impuros zeros nãos que nãoam nãoam nãoam/ o pluriuno nãoão ao morbo amorfo innão/ não dêmono/ não deo/ sem som sem sexo nem órbita/ o hirto inósseo innão no uníssolo amódulo/ sem poros já sem nódulo/ nem eu nem cova nem fosso/ o macro não nem polvo/ o não mais nada tudo/ o puro não/ sem não" (GIRONDO, 1999, p. 765).

${ }^{2}$ Os três volumes de Eugen Dühring foram imodestamente intitulados de "Sistema completo de filosofia - filosofia intelectual, moral, natural e da história", "Sistema completo de economia política e de socialismo" e "História crítica de economia política", ante os quais Engels replicou escrevendo seus "A subversão da ciência pelo Sr. E. Dühring - AntiDühring" e "Do socialismo utópico ao socialismo científico".

${ }^{3}$ A partir de esta constatação é que discordamos da opinião de Agamben acerca dos limites da crítica de Marx, os quais residiriam "no fato de que ele não consegue superar a ideologia utilitarista, segundo a qual o gozo do valor de uso é a relação originária e natural do homem com os objetos, escapando-lhe por conseguinte a possibilidade de uma relação com as coisas que vá além do gozo do valor de uso, quanto daquele da acumulação do valor de troca”. (AGAMBEN, 2007b, p. 83). Cremos ser plausível encontrar em Marx o "valor profanatório" ou o puro-não-valor dos objetos, conforme o trecho que segue: "na sociedade comunista, onde cada indivíduo não tem para si um círculo exclusivo de atividades, mas pode desenvolver suas aptidões no ramo que melhor lhe aprouver, a sociedade se encarrega de regular a produção universal, com o que ela torna possível, justamente através disso, que eu possa me dedicar hoje a isto e amanhã àquilo, que possa caçar pela parte da manhã, pescar pela parte da tarde e à noite apascentar o gado, e depois de comer, criticar, se for o caso e conforme meu desejo, sem a necessidade de por isso me tornar caçador, pescador, pastor ou crítico algum dia” (MARX; ENGELS, 2007, p. 56).
} 
4 Para Freud, "se eliminarmos os direitos pessoais sobre a riqueza material, ainda permanecem, no campo dos relacionamentos sexuais, prerrogativas fadadas a se tornarem a fonte da mais intensa antipatia e da mais violenta hostilidade entre homens que, sob outros aspectos, se encontram em pé de igualdade" (FREUD, 1974, p. 135-136).

${ }^{5}$ Atente-se para o fato de a tradução brasileira (“dispõe”) divergir da tradução de Agamben (depõe).

${ }^{6}$ Agamben, inquirindo sobre as origens do termo "muçulmano" em Auschwitz, escapa às possíveis controvérsias semânticas - que levariam a observar se tratar de um preconceito religioso - e assevera: "em todo caso, o certo é que, com uma espécie de feroz auto-ironia, os judeus sabem que em Auschwitz não morrerão como judeus". (AGAMBEN, 2008, p. 53). Já Jeanne Marie Gagnebin, ao apresentar a edição brasileira do livro de Agamben, sentencia: "a etimologia dessa expressão 'muçulmano' é obscura; da minha parte não consigo não ouvir, em todas laboriosas explicações, como que uma certa desforra de caráter racista na boca das vítimas do anti-semitismo". (GAGNEBIN, 2008, p. 13).

${ }^{7}$ Os três tipos penais são os artigos 16 ("integrar ou manter associações, partido, comitê, entidade de classe ou grupamento que tenha por objetivo a mudança do regime vigente ou do Estado de Direito, por meios violentos ou com emprego de grave ameaça"), 17, cabeça ("tentar mudar, com emprego de violência ou grave ameaça, a ordem, o regime vigente ou o Estado de Direito") e 23, inciso I (“incitar à subversão da ordem política ou social”). E ainda a comunidade jurídica à época (1983, ainda durante a ditadura militar!) saudou a lei como empreendimento democrático da transição brasileira: "a nova lei de segurança representa um avanço notável que não pode deixar de surpreender os que se opõem ao sistema político em vigor. A doutrina da segurança nacional, elaborada pela Escola Superior de Guerra, parecia ser a alma do sistema. A nova lei tende a tornar raros os processos por crime contra a segurança do Estado" (FRAGOSO, 2004, p. 7).

${ }^{8}$ No original, há uma nota de rodapé ao final da citação remetendo ao "Homo sacer I", de Agamben.

${ }^{9}$ Incorporamos, aqui, a crítica de Dussel a Agamben, entendendo-a como expressão de certa complementaridade ao pensamento dos dois autores: "el contenido (o la materia) de toda política (de sus actos, instituciones, etc.) es en ultima instancia la vida humana, la vida concreta de cada uno, la 'vida desnuda' - más concreta que la nuda vita de G. Agamben" (DUSSEL, 2006, p. 73). 